\title{
The Relationship between Saving and Investment: The Case of Saudi Arabia
}

\author{
Abdulelah Alrasheedy ${ }^{1} \&$ Hamed Alaidarous ${ }^{1}$ \\ ${ }^{1}$ Economic Research Department, Saudi Arabian Monetary Authority, Saudi Arabia \\ Correspondence: Abdulelah Alrasheedy, Economic Research Department, Saudi Arabian Monetary Authority, \\ Saudi Arabia. E-mail: asalrashidi@sama.gov.sa
}

Received: September 5, 2019

Accepted: October 25, 2019

Online Published: October 30, 2019

doi:10.5539/ijef.v11n11p64

URL: https://doi.org/10.5539/ijef.v11n11p64

\begin{abstract}
It is an attempt to investigate the relationship between saving and investment and the mechanism of the way they influence the economic growth. It is very vital to study such causality to help policy makers setting out appropriate economic policies. It is taking us too long to come up with the results because of the lack of data, and the complexity of how saving and investment defined in case of Saudi economy. The results show that there is a bidirectional granger causality between private saving and private GDP, and unidirectional causality running from private saving to private investment. However, there is an ambiguous relationship missing between investment and economic growth at both aggregate and private levels. Finally, although this study shows the directional of causality between the three considered variables, the study could not catch up the magnitude of the impact of these variables on each other.
\end{abstract}

Keywords: Saudi Arabia, saving, investment, causality, Feldstein's and Horioka's theory (FH)

\section{Introduction}

This paper attempts to investigate the relationship between saving and investment, as well as the mechanisms of how they influence economic growth in the case of Saudi Arabia. The declaration of such a causality will prove invaluable in helping policymakers to set out the effective economic policies. Studying the relationship between savings and investment is complicated because it necessitates a consideration of a multitude of factors concerning the nature of the variables i.e. the data, and theories applicable to these variables. Thus, saving-investment relationship has long been a subject of debate between economic schools of thought. Each school shows a different methodology in explaining the causality between saving and investment and their transition mechanisms to economic growth. The literature relevant to this relationship can be divided into two main categories: theoretical and empirical literature. For the sake of simplicity, one can most effectively divide the literature on the saving-investment relationship into two approaches: heterodox and orthodox economic approaches, which are both supported by empirical evidence. The following sections of this paper will be organized to illustrate the following: part two is dedicated to discuss the theoretical literature of saving-investment relationship, part three covers the empirical literature, part four introduces the data and the empirical framework of the study, part five shows the empirical work and results.

\section{Theory of Saving and Investment}

The modern neoclassical view of saving is rooted in Marshall's microeconomic view of saving. Neoclassical economists argue that the level of saving determines the level of investment and equilibrium interest rate. Thus, from this perspective saving is a function of thriftiness; the demand for investment is a function of the marginal productivity of capital. Saving is therefore the way to increase investment spending, which subsequently increases capital accumulation and ultimately increases economic growth. However, there are several criticisms and limitations of the neoclassical view.

The basis of Keynes' position on the neoclassical theory of saving and investment is that saving is not as simple as neoclassical thought, rather, it is a two-step process as opposed to a single process. Keynes tends to view saving as a process broken down into two parts; marginal propensity to consume and marginal propensity to save, thereby saving for Keynes, it is not only thrifty (neoclassical), but income is also considered. In this sense, the first part to saving is first acquiring the income before deciding how much to consume or save. Thus, to determine how much saving is ideal, one first needs income, and then the propensity to consume follows. Income 
is determined by the point of effective demand, effective demand determines employment, and income is determined by employment. However, employment is determined by investment, which depends on marginal efficiency of capital as an expectation in terms of money value. To sum up this perspective, saving never acts as a source of investment and never deviates from investment so $\mathrm{S}=\mathrm{I}$ (Terzi, 1986).

Economists like Marc Lavoie (Foundations of PK Economic Analysis, 1992), Karl Lutz (Economics for the Common Good, 1999), and Fuller (An Alternative to PK Household Consumption Theory, 1996) have argued that neoclassical economists emphasize saving and not consumption i.e. there could be no role for consumption in economic growth. Unlike the classical and neoclassical economists, Post Keynesians argue that, at the macro level, one cannot save something that does not exist. Thus, the income must exist to be saved; the income is derived from investment so ultimately investment determines how much can be saved. In heterodox economic schools of thought investment must necessarily come before saving can take place. Keynes, in his General Theory of Employment, Interest, and Money (1936) introduced us to the paradox of thrift. This idea basically states that saving reduces spending and thus is detrimental to economic growth. Unlike neoclassical and classical economists who assume that savings will be later spent on investment, Keynes did not make this assumption. Instead, Keynes believed that when we choose to save, the money is not being recycled back into the economy through investment or consumption of goods or services. This would result in a weakening of effective demand which would subsequently reduce aggregate national income, lower employment, and ultimately limit economic growth.

Instead, Keynes argued that for a nation to accumulate capital and, thus, achieve economic growth, there must be a level of effective demand consistent with the level of full employment. This means that, when the nation wants to increase growth, investment and consumption should be emphasized and promoted as much as possible. In Keynes' world, consumption plays an even more crucial role than saving in economic growth. Post Keynesians have taken after Keynes's assertion of the lack of relationship between saving and capital accumulation. Wray, in "Saving, Profits, and Speculation in Capitalist Economies" and in Understanding Modern Money, has argued that economic growth requires deficit spending that generates a surplus elsewhere (Wray, 1991; 1998). Therefore, Wray argued the economy does not need saving to finance investment but rather, it needs credit creation i.e. endogenous money is necessary for growth. In a post-Keynesian world, investors must borrow to run their business including wages paid to workers. In the context, the investors must ensure that the workers spend as much of their income so the investors can eventually recuperate the expenditures borrowed to finance the wages. If workers decide to save a large portion of their income instead of spending, then the investors must find a way to get these savings circulated back into the economy by selling them non-producible goods like bonds, stocks, etc. In this way, the investors get back the wage bill expenditures. At the same time, whatever the investors spend on consumption of goods and investment finally returns to them as gross profits. As we can see, workers' failure to spend all of their income on consumption or non-producible goods or investors' failure to spend on consumption or investment goods will reduce the investors' gross profits. In short, one can see that in the Post Keynesian's world, saving cannot finance investments, but investment can however cause saving through the creation income.

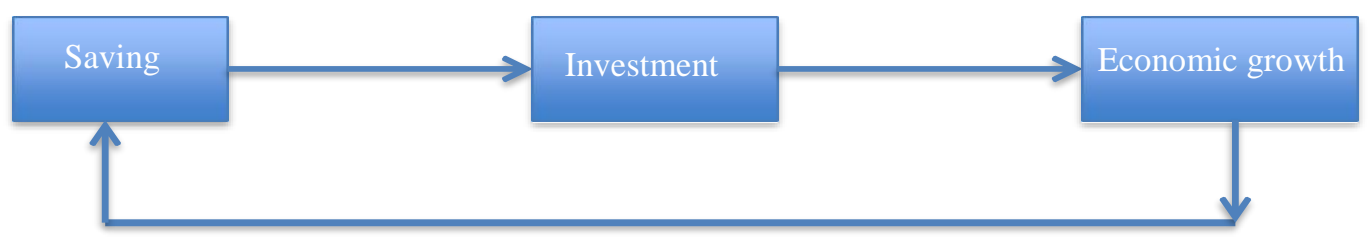

Figure 1. Orthodox economic thought of saving and investment

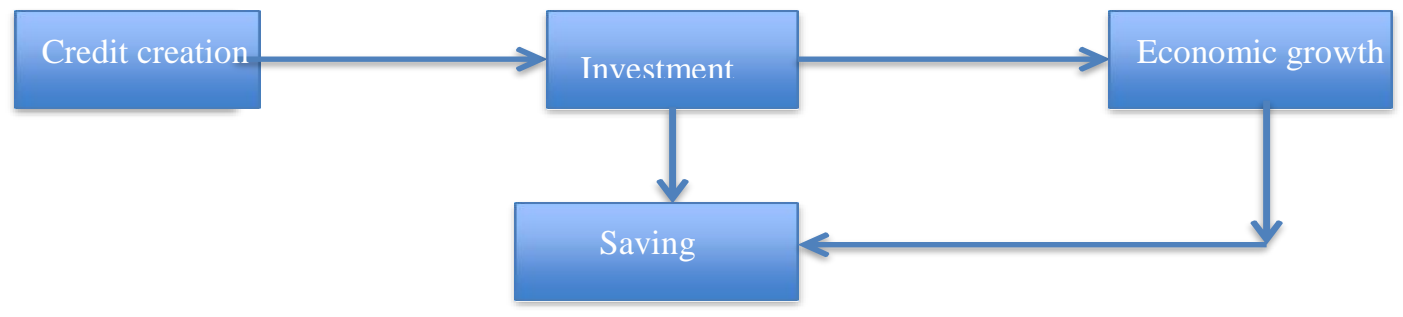

Figure 2. Post-Keynesian economic thought of saving and investment 
An accurate understanding of the nature of investment and saving relationship is especially crucial for Saudi Arabia. This paper thus contains both a theoretical and empirical analysis to obtain coherent indicators of the nature of the causal relationship between saving and investment and their mechanisms enhancing the economic growth. Thus, the next section shall illustrate some empirical evidence for the nature of the causal relationship between these variables.

\section{Empirical Literature Review}

Theoretical and statistical studies have shown that there is a relationship between saving and investment. However, the relationship will vary depending on a country's economic structure. This paper is endeavoring to create a clear picture of the relationship between saving and investment and economic growth in the case of Saudi Arabia. Thus, this section

is dedicated to exploring empirical work concerning the relationship between saving and investment and whether the empirical data support the orthodox economic thought or the heterodox economic thought on the saving and investment relationship. In their 1980 paper, Feldstein and Horioka proposed that existence of the relationship between saving and investment would not appear under the perfect capital mobility (this finding named as $\mathrm{FH}$ hereafter or FH puzzle in the literature). In context, when there is perfect capital mobility, the national saving would follow wherever the highest return is; in turn, the relationship between a nation's saving and investment would disappear. In their paper, in the absence of perfect capital mobility, the empirical data tend to support the orthodox economic view of saving and investment relationship i.e. saving causes investment.

Miller's study (1988), which utilized Engle's and Granger's causality method with annual data from 1948-1987, revealed a clear positive causal relationship between savings and investment in the economy of Latin America. This positive causal relationship is clear in the pre-World War II period and with a fixed exchange rate regime. In other words, miller's research was consistent with Feldstein's and Horioka's theory (FH). However, De Vita and Abbott in their study (2002) found that capital mobility resulted in a weakening of the coefficient between saving and investment since 1971 which is compatible with FH theory stating that saving does not cause investment under conditions of perfect capital mobility. In context, Kim used a panel of annual data spanning from 1958 to 1992 and covering 62 countries with varying economic structures to further test the FH theory. Kim's findings showed that the positive causal relationship between savings and investment holds true in the case of OECD member countries that have less capital mobility compared to the developed economies that have perfect capital mobility. Moreover, Caporele and Panopoulou (2005) selected five Latin American countries and employed the Johansen- Juselius method to test the cointegration relationship between savings and investment during the period from 1950 to 1994. Panopoulou and Caporele found that there was positive causal relationship between saving and investment in the long-run.

In 2000, Tan Hui used Engle-Granger method on five "ASEAN" countries to test for a long run relationship between savings and investment during the period of 1967-1997 using a vector auto correction model. Tan Hui's findings revealed that there was strong long-run causal relationship between savings and investment in "ASEAN" countries. Bassam (2006) used Granger's causality test to test the causal relationship between savings and investment in four countries: Egypt, Morocco, Jordan, and Tanzania, during the period from 1962 to 2002. While part of Bassam's results indicates a unidirectional causality running from investment to savings in the cases of Morocco and Egypt and from saving to investment in the case of Jordan, his data on Tanzania revealed bidirectional causality between saving and investment. Thus, Bassam's results simultaneously support both heterodox and orthodox views on the saving-investment relationship.

Moreover, these causal relationships hold throughout much of history up until recent years. For instance, Tehranchian and Behravesh utilized the Error Correction model to study the relationship between saving and investment in Iran. Tehranchian's and Behravesh's results indicate a long-run equilibrium relationship between savings and investment and direct significant effect of savings on investment in the long-run rather than in the short run.

In 2010, Kaya's paper aimed to investigate domestic saving-investment relationship in the case of Turkey. This paper used Feldstein and Horioka's (1980) approach posits that the saving-investment relationship would not be detectable in the case of perfect capital mobility. This paper used ARDL bound testing procedure to test whether the FH point of view holds for Turkey which has experienced full capital account liberalization since 1989. This paper used two different data sets: private investment-saving, and total investment- saving over the period of 1984Q1-2007Q3. Kaya's findings indicated that there is strong long-run relationship between total investment and saving. On the other hand, they found no significant long-run relation between private saving and investment. However, the authors interpreted these two conflicting results as being the product of a constraint caused by 
balance of payment targeting and/or solvency.

Moreover, Nasiru and Usman (2013) explored the relationship between savings and investment in Nigeria during the period 1980-2011. The utilized Autoregressive Distributed Lag(ARDL) bounds testing approach to test for long run relationship and used the error correction model (ECM) to capture the short-run dynamic. Nasiru and Usman results are consistent with a number of previous studies that revealed that savings and investment are cointegrated in the long-run and compatible with Feldstein-Horioka(1980) view.

\section{Data and Empirical Framework}

In this paper, four variables were used in order to understand the relationship between saving and investment in the context of Saudi economy; those are the following: 1) gross domestic product (y), 2) investment (i), 3) fiscal budget balance (bb), and 4) current account balance (CAB). As the objective of this study is to examine the impact of dynamic saving and investment relationship on real Saudi economy, GDP deflator measures were used to convert the designated variables from nominal to real. Based on the purpose of this study, the three main variables, through which the objectives of the study can be reached,

are as follows: real gross domestic product (y), investment (i) and saving (s). These three variables will be represented in terms of total and private (Note 1). The annual GDP and investment series are derived directly from the national accounts reports, published by the GASTAT. Saving, on the other hand, is indirectly derived by using the following identity:

$$
S=I+C A B
$$

This equation shows that national saving, $S$, has two components: 1) the aggregate capital stock, which is accumulated through an increase in gross fixed capital formation (investment), and 2) the stock of foreign assets which represents the accumulation of loans to foreigners or acquiring foreign assets; in an amount equal to the current account balance, $\mathrm{CAB}$. In the same vein, private saving has been derived in this study by using the following identity; total saving $=$ private saving + government saving $(\mathrm{bb}) ; \mathrm{St}=\mathrm{Sp}+\mathrm{Sg}$.

\subsection{The Transmission Mechanism of Saudi Arabia Through Variables}

In the case of Saudi economy, figure 3 illustrates the behavior and interaction between variables. For instance, one can realize that the saving has a positive relationship with economic growth, which is compatible with the economic theory. In essence, when there is an increase in economic growth, the saving is expected to increase. Moreover, the saving increases as the oil prices increase as shown in figure 4, which is the main driver of the Saudi economic growth through government spending. Furthermore, from the figure 4 one can see that the largest part of the saving is demonstrated by investment. However, the interaction and causality between investment and saving and economic growth cannot be recognized from both figures. Therefore, this kind of task (indicating the causality) will be illustrated in the following sections.

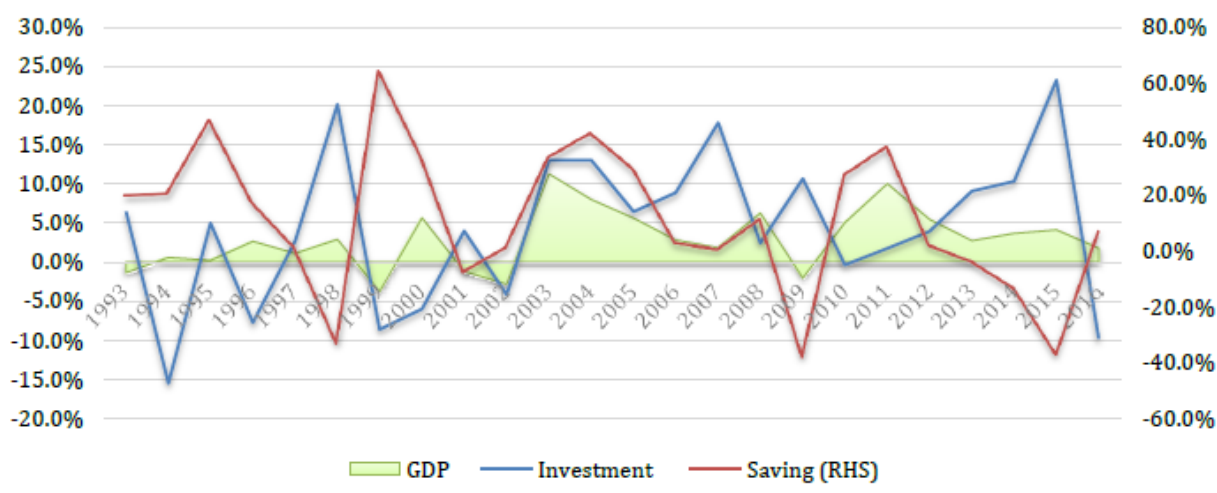

Figure 3. Saving, Investment, and Real GDP Growth Rates 


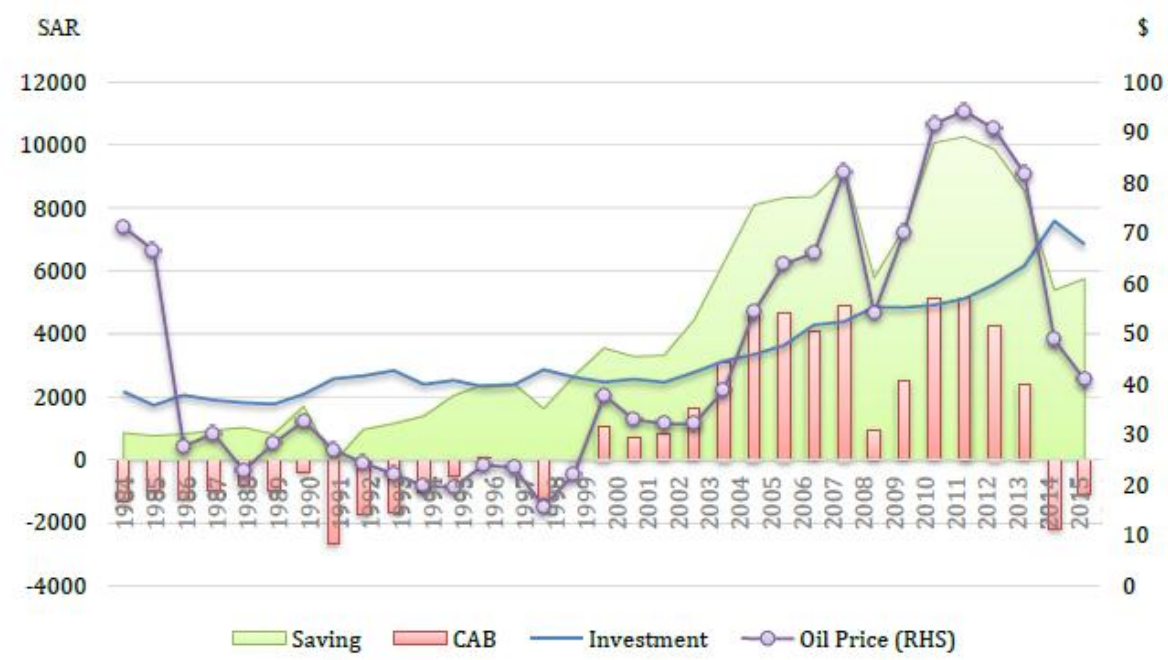

Figure 4. Saving components and oil price, in real terms

\subsection{Econometric Method}

In this section, the paper endeavors to illustrate the direction of the causality between six variables by utilizing standard Granger causality. The sample period is 1984 to 2016 . The econometric procedure is divided into several stages such as: testing the unit root in the variables by using Augmented Dickey-Fuller test. This test is necessary to ensure whether the variable is stationary or non-stationary- if the variables are non- stationary, then our model would become spurious or results would be unreliable. Also, the stationary variable is a prerequisite for the implementation of Granger Causality tests (Granger, 1969).

\section{A). Augmented Dickey-Fuller Unit Root Tests}

In this section, the unit root test will be conducted in order to test whether the variables have unit roots or not. A variable has a unit root if the value of the variable does not fluctuate around zero mean and constant variance. In order to search for this, the variables will be tested in their levels and in first differences or second difference. To do this, the Augmented Dickey-Fuller unit root tests will be used (Dickey \& Fuller, 1979, 1981). For all six time series variables the tests will be based on model with constant.

\section{(a) With Constant and Without Trend}
1) $S t t=\alpha+\delta S t t-1+\mu t$
2) $S p t=\alpha+\delta S p t-1+\mu t$
3) $I t=\alpha+\delta I t t-1+\mu t$
4) $I p=\alpha+\delta I p t-1+\mu t$
5) $Y t=\alpha+\delta Y t t-1+\mu t$
6) $Y p=\alpha+\delta Y p t-1+\mu t$

\section{The hypotheses are:}

If $\mathrm{H} 0: \delta=0$, we have a unit root.

Otherwise, $\mathrm{H} 1 \delta \neq 0$, we do not have a unit root. By using t-test:

If $\mathrm{t}>\mathrm{ADF}$ critical Value, fail to reject the null hypothesis, and a unit root exists. If $\mathrm{t}<\mathrm{ADF}$ critical Value reject null hypothesis, and a unit root does not exist. 
Table 1. Unit root results

\begin{tabular}{lll}
\hline Variable & Test statistic & Results \\
\hline (Total Saving) & -1.255 p-v 0.637 & \\
D (Total Saving) & -5.255 p-v 0.000 & $\mathrm{I}(1)$ \\
(Private Saving) & 0.235 p-v 0.970 & \\
D (Private Saving) & -10.691 p-v 0.000 & $\mathrm{I}(1)$ \\
(Total Investment) & 0.948 p-v 0.994 & \\
D (Total Investment) & -5.715 p-v 0.000 & $\mathrm{I}(1)$ \\
(Private investment) & 0.106 p-v 0.961 & $\mathrm{I}(1)$ \\
D (Private investment) & -4.653 p-v 0.000 & \\
(Total Y) & 1.162 p-v 0.997 & $\mathrm{I}(1)$ \\
D (Total Y) & $-5.987 \mathrm{p}$-v 0.000 & \\
(Private Y) & $-2.532 \mathrm{p}$-v 0.118 & $\mathrm{I}(2)$ \\
D (Private Y) & -1.806 p-v 0.370 & \\
DD (Private Y) & $-6.021 \mathrm{p}$-v 0.000 & \\
\hline
\end{tabular}

Sources: Author's Computation.

Note. D stands for the first difference of the variables; and the DDD stands for the second difference for the variable.

The results in the table 1 reveal that all variables are non-stationary at their levels. Thus, it is clear that the null hypothesis (variable has a unit root) cannot be rejected at 5 percent. However, all variables became stationary after taking the first difference, except private GDP which became stationary after taking second difference. Therefore, the test reveals that all variables are integrated of order 1, i.e. I (1) except Private GDP is integrated of order 2, i.e. I (2). Now, we are in good position to conduct run standard Granger Causality tests on two different data sets i.e. aggregate level and private level.

Table 2. Standard Granger Causality Test for aggregate level

\begin{tabular}{|c|c|c|c|}
\hline$\underline{\text { Direction }}$ & of causality & Optimal lag & Test statistic \\
\hline Null D (St) does not cause D (It) & Ambiguous/ no clear & 2 & $0.831 \mathrm{p}-\mathrm{v} 0.447$ \\
\hline Null D(It) does not cause (St) & Granger causality & 2 & $0.317 \mathrm{p}-\mathrm{v} 0.731$ \\
\hline Null D(It) does not cause D(Yt) & Ambiguous/ no clear & 2 & $0.30215 \mathrm{p}-\mathrm{v} 0.741$ \\
\hline Null D(Yt) does not cause D(It) & Granger causality & 2 & $1.62527 \mathrm{p}-\mathrm{v} 0.217$ \\
\hline Null D(Yt) does not cause D(St) & Ambiguous/ no clear & 2 & 1.64447 p-v 0.213 \\
\hline Null $\mathrm{D}(\mathrm{St})$ does not cause DD(Yt) & Granger causality & 2 & $0.36526 \mathrm{p}-\mathrm{v} 0.697$ \\
\hline
\end{tabular}

Sources: Author's Computation.

Note. Using AIC to indicate optimal lag length.

The results in table 2 reveal that there is not Grange causality running between all three variables, in turn, the results are compatible with Feldstein and Horioka (1980) (FH hereafter or FH puzzle in the literature) point of view in which the saving-investment relationship would not exist in the case of perfect capital mobility because in case of perfect capital mobility savings follow wherever the highest return is, in turn the relations between saving and investment melt. However, this study approaches this relationship through another way by having different data set i.e. private saving, private investment, and private GDP. Therefore, the following section will illustrate the relationship, using Granger Causality test, between new variables.

Table 3. Standard Granger Causality Test for private level

\begin{tabular}{|c|c|c|c|}
\hline Direction & Direction of causality & Optimal lag & Test statistic \\
\hline Null D (Sp) does not cause D (Ip) & $\mathbf{D}(\mathbf{S p}) \Rightarrow \mathbf{D}(\mathbf{I p})$ & 2 & 5.022 p-v 0.014 \\
\hline Null D(It) does not cause (St) & & 2 & 0.169 p-v 0.845 \\
\hline Null D(It) does not cause DD(Yp) & Ambiguous/ no clear & 2 & 1.464 p-v 0.251 \\
\hline Null DD(Yt) does not cause $D(I t)$ & Granger causality & 2 & 0.712 p-v 0.500 \\
\hline Null DD(Yt) does not cause $D(S t)$ & $\mathbf{D D}(\mathbf{Y t}) \Leftrightarrow \mathbf{D}(\mathbf{S t})$ & 2 & 2.543 p-v 0.099 \\
\hline Null D(Sp) does not cause DD(Yp) & & 2 & 3.349 p-v 0.052 \\
\hline
\end{tabular}

Sources: Author's Computation.

Note. Using AIC to indicate optimal lag length. 
The results in table 2 reveal that private saving Granger causes private investment, in turn saving play crucial role in the private investment. Moreover, there is bidirectional Granger causality running between private GDP private saving. However, there is no existence of Granger causality between private investment and private GDP. The former findings can be attributed to the fact that the government expenditure (Fiscal policy) is the main driver of the both total growth of GDP and Private GDP in the case of Saudi economy.

\section{Conclusion}

The main takeaways of this study can be summarized into three points:

First, given the current Saudi economic structure which support perfect capital mobility concept, the findings of this study implies that there is not Grange causality running between all three aggregate variables, in turn, because in case of perfect capital mobility savings follow wherever the highest return is, in turn the relations between saving and investment melt. Eventually, this finding is compatible with Feldstein and Horioka (1980) (FH hereafter or FH puzzle in the literature) point of view in which the saving-investment relationship would not exist in the case of perfect capital mobility.

Second, the study reveals that there is a bidirectional granger causality between private GDP and private saving. In addition, the study shows the granger causality is also running from private saving to private investment, which is consistent with the economic theory. However, granger causality test reveals that there is no casualty running from private investment to private GDP i.e. the relationship between private investment and private GDP melt. By knowing that, there is a missing part needed to complete the full picture of dynamic mechanism effects between these variables, as it is represented in economic theory. The disconnection between investment and economic growth can be attributed to some reasons such as: first, the main driver of private sector is the government expenditure rather than private investment; second, the kind of investments in the private sector could be inefficient or has very small impact on the economic growth; third, other factors including business environment, legal framework and lack of transparency, where the third reason is expected to be tackled within the recent economic measures.

Third, given the current economic reforms especially the current expansion in both external and internal debts, the saving's contribution to the economic growth would decrease because government's bonds or sukuk will be more attractive for the investors rather than other economic activities, due to the less risk associated with this kind of bonds. By noticing the saving identity, one can realize that the government's debt services could affect the dynamic mechanism of saving on growth.

Finally, although this study shows the directional of causality between the three considered variables, the study could not catch up the magnitude of the effect of these variables on each other.

\section{References}

Bassam, A. (2006). The relationship between savings and investment in MENA countries. Retrieved from https://www.usi.edu/media/3654875/Relationship-Between-Savings.pdf

Caporale, G. M., Panopoulou, E., \& Pittis, N. (2005). The Feldstein-Horioka puzzle revisited: A monte carlo study. Journal of International Money and Finance, 24(7), 1143-1149. https://doi.org/10.1016/j.jimonfin.2005.08.003

De Vita, G., \& Abbott, A. (2002). Are saving and investment cointegrated? An ARDL bounds testing approach. Economics Letters, 77(2), 293-299. https://doi.org/10.1016/S0165-1765(02)00139-8

Dickey, D. A., \& Fuller, W. A. (1979). Distribution of the estimators for autoregressive time series with a unit root. Journal of the American Statistical Association, 74(366a), 427-431. https://doi.org/10.1080/01621459.1979.10482531

Dickey, D. A., \& Fuller, W. A. (1981). Likelihood ratio statistics for autoregressive time series with a unit root. Econometrica: Journal of the Econometric Society, 1057-1072. https://doi.org/10.2307/1912517

Feldstein \& Horioka, C. (1980). Domestic Saving and International Capital Flows. Economic Journal, 90, 314-29. https://doi.org/10.2307/2231790

Feldstein, M. S., \& Horioka, C. Y. (1979). Domestic savings and international capital flows. https://doi.org/10.3386/w0310

Fuller, C. G. (1996). Elements of a Post Keynesian Alternative to "Household Production". Journal of Post Keynesian Economics, 18(4), 595-607. https://doi.org/10.1080/01603477.1996.11490089

Kaya, H. (2010). Saving Investment Association in Turkey. Topics in Middle Eastern and North African 
Economies,

12.

Retrieved

from

https://ecommons.luc.edu/cgi/viewcontent.cgi?referer=https://scholar.google.com/scholar?hl=en\&as_sdt=0 $\% 2 \mathrm{C} 5 \& \mathrm{q}=$ Kaya\%2C+H.+\%282010\%29.+Saving+Investment+Association+in+Turkey.+Topics+in+Middle + Eastern+and+North+African + Economies $\% 2 \mathrm{C}+12 \& \mathrm{btnG}=\&$ httpsredir $=1 \&$ article $=1125 \&$ context=meea

Keynes, J. M. (2016). General theory of employment, interest and money. Atlantic Publishers \& Dist.

Kim, S. H. (2001). The saving-investment correlation puzzle is still a puzzle. Journal of International Money and Finance, 20(7), 1017-1034. https://doi.org/10.1016/S0261-5606(01)00030-4

Lavoie, M. (1992). Foundations of post-Keynesian economic analysis. Books. https://ideas.repec.org/b/elg/eebook/275.html

Llorca, M. (2008). Macro-financial developments of Slovakia: An empirical analysis based on the monetary circuit theory. http://citeseerx.ist.psu.edu/viewdoc/download?doi=10.1.1.563.937\&rep=rep1\&type=pdf

Lutz, M. A. (2002). Economics for the Common Good: Two Centuries of Economic Thought in the Humanist Tradition. Routledge. https://doi.org/10.4324/9780203439272

Miller, S. M. (1988). Are saving and investment co-integrated?. Economics Letters, 27(1), 31-34. https://doi.org/10.1016/0165-1765(88)90215-7

Nasiru, I., \& Usman, H. M. (2013). The relationship between domestic savings and investment: The Feldstein-Horioka test using Nigerian data. CBN Journal of Applied Statistics, 4(1), 75-88. https://www.econstor.eu/handle/10419/142074

Tan-Hui, B. (2000). Savings, Investment and Capital Flow: An Empirical Study ON THE Asean Economics. Department of Economics Faculty of Economics and Management, University Putra Malaysia, Working Paper https://www.researchgate.net/publication/228433991_Savings_Investment_and_Capital_Flows_An_Empiri cal_Study_of_the_ASEAN_Economies

Tehranchian, A. M., \& Behravesh, M. (2011). The relationship between savings and investment in Iran: Testing Feldstein's and Horioka's theory. African Journal of Business Management, 5(4), 1408.

Terzi, A. (1986). Finance, investment and saving: A comment on Asimakopulos. Cambridge Journal of Economics, 10(1), 77-80.

Wray, L. R. (1991). Saving, profits, and speculation in capitalist economies. Journal of Economic Issues, 25(4), 951-975. https://doi.org/10.1080/00213624.1991.11505226

Wray, L. R. (1998). Understanding modern money (Vol. 11). Cheltenham: Edward Elgar. https://doi.org/10.2139/ssrn.137409

\section{Note}

Note 1. This study consists of two models based on aggregate variables and the relevant private variables. Therefore, the total variables used is six including aggregate investment, aggregate saving, aggregate GDP, private saving, private investment, and private GDP.

\section{Copyrights}

Copyright for this article is retained by the author(s), with first publication rights granted to the journal.

This is an open-access article distributed under the terms and conditions of the Creative Commons Attribution license (http://creativecommons.org/licenses/by/4.0/). 